results were more illuminating. Though consistency was generally aimed at, an individual's reactions, it appeared, were seldom completely consistent and might be based on changing standards as the trial proceeded. The order in which the material was presented might be important, and there was also a problem in the actual quantity of the test material that should be provided. It was possible that the subject might learn about the technique of making comparisons as the test proceeded, and also that an initial preference might turn almost to nausea before the trial was over. Mr. Babington Smith distinguished between 'competitor's' and 'co-operators' among his subjects; the former seemed anxious to find what they felt to be the 'right' answer, whereas the latter did more nearly what they were asked, which was to provide a straightforward description of their reactions. The first type might be useful on expert tasting panels, and the second, who might perhaps be regarded as having the instincts of a gourmet, would be useful in a consumer tasting panel.

Several speakers in the subsequent discussion were not happy about this classification. Mr. Babington Smith indicated that he did not intend a rigid classification into psychological types, his description only applying within the framework of the experiment; he also agreed that there might be a tendency for the less-experienced tasters to be anxious to find the 'right' answer, whereas the more experienced individual was more likely to be relaxed and confident in his appreciations.

The third main speaker, Mr. W. J. Gleeson (Reckitt and Colman, Ltd., Norwich), described a problem on market research for a food manufacturer. This was admittedly in the strict sense an unscientific business, but it was demonstrably possible for consumer surveys of this kind to convey information of which the manufacturer was not aware, and to indicate that the consumer had detected something that the manufacturer had not expected him to notice. The consumer in any event liked to be asked his opinion and would volunteer it even if he was not asked; and so they asked him. One of the principal difficulties in this type of work arose from the fact that the consumer would subsume all the factors affecting his preference, even colour, into the omnibus expression 'flavour'. Other difficulties arose from the necessity to compensate statistically so far as possible for the kind of error-inducing factors which had already been described by Mr. Babington Smith.

During the general discussion, some attention was given to the inevitability, or desirability, according to one's point of view, of using a combination of two or more of the senses in arriving at a subjective judgment of quality. In this connexion, Prof. H. D. Kay (National Institute for Research in Dairying, Shinfield) referred to cheese, Dr. H. J. Strausz (consultant chemist) to essential oils, and Mr. H. J. Bunker (consultant microbiologist) - who started with the story of the small girl who said she could hear the bacon smelling-to beer. Mr. Bunker's work, in contrast to most of the rest, was concerned with expert tasting in pursuit of the maintenance of a standard rather than with consumer preferences. In his field, the powerful assault of hops on the palate provided one of the major difficulties to extended tasting tests. Dr. G. Slot (physician) referred to the deliberate addition of emotional overtones to consumer preference, and instanced his hospital patients, who greatly preferred an expensive but widely advertised glucose drink to his own free prescription for the same material, as well as to those patients who reacted quite differently to red pills and blue pills even when both were aspirin. Mr. R. B. D. Stocker, as a dentist, picked up a reference made by Mr. Gleeson to fashions in taste, and said that in recent years the public taste had changed in a manner inimical to health. Mr. J. M. Harries (Ministry of Agriculture, Fisheries and Food) emphasized that one should not accept a stated preference as valid unless one had previously established the subject's ability to differentiate between the materials on trial, and Dr. Hugh Davson (University College, London) expressed the distaste of a physiologist for experiments in which the subject was asked to express a preference as opposed to those in which he was merely asked if he could tell the difference between two stimuli. Perhaps the last word lay with Dr. Kalmus, who thought that the whole subject would probably remain largely empirical and that it would be a long time before any sweeping, unifying theory emerged.

D. Nevillie-JoNES

\section{USE OF ISOTOPES IN AGRICULTURE}

$T$ HE European Contact Group on the uses of isotopes and radiation in agricultural research has been established by the Food and Agriculture Organization of the United Nations to provide a medium for the exchange of information between European countries on present and planned programmes with the view of identifying applications likely to be of greatest significance for European agriculture. The object is to enable countries to pool their knowledge and experience for the common good and to make most effective use of the facilities available. The first meeting took place at Wageningen, in Holland, during December 10-14, and a report of the proceedings has recently been published*. It was attended by thirty-one representatives of sixteen European member governments and by observers from the United States and the U.S.S.R. and eight international organizations. Dr. S. L. Mansholt, Minister of Agriculture, Fisheries and Food in the Netherlands Government, announced that his Govern. ment had decided to establish an institute at Wageningen for the application of atomic energy in agriculture and as a centre of research, instruction and information. He expressed the hope that this would not remain a purely national institute, but would in due course develop into a European centre for the application of atomic energy in agriculture.

Discussions on the use of isotopes and radiation in agricultural research were organized under five subject headings. The topics concerned with the use of isotopes in soil science included the validity of the isotope technique, determination of active fractions of various soil ions by the isotope-dilution technique, use of labelled fertilizers, vertical migration of soil ions, exchange of ions between roots and medium, and evolution of organic matter in the soil. The delegations described how isotopes are being used in

* Food and Agriculture Organization of the United Nations. European Commission on Agriculture: Sub-Commission on Agricultural Research. Report of the First Meeting of the European Contact Group on the Uses of Isotopes and Radiation in Agricultural Research, held in Wageningen, Netherlands, 10-14 December, 1956. Pp. ii +39 . (Rone
Nations, 1957.) 
plant science to study such subjects as absorption of ions by leaves, uptake of minor elements, photosynthesis and sap movement in trees. The use of isotopes in animal science fell approximately into four categories, namely, intermediary metabolism, mineral metabolism, endocrinology and reproduction.

The fact that the genetic materials-the genes and chromosomes-are highly sensitive to ionizing radiations which induce hereditary changes or mutations has led to the exploration of the possibility of using this technique in improvernent of crops. So far the method has been little used in animal breeding. 'The delegations indicated that useful mutations of cereals and other crops were being obtained.

The Group also discussed the reports which several countries presented on the use of radiation in the preservation and processing of food. This work is still in the developmental stage, and important problems need further investigation. At the moment, the destruction of insects in stored products, the suppression of sprouting in potatoes and root crops and the treatment of some fresh meats would appear to be the most promising applications of ionizing radiation to foods.

The nature of the financial provisions required for research programmes involving the use of isotopes and radiation was discussed, and the delegations made statements on the scope of training facilities for isotope research. Consideration was also given to the design and equipment of isotope laboratories for agricultural research. Attention was directed to the need for an international list of available labelled compounds. For the future, the Group agreed to continue its activity in organizing special meetings or symposia in particular aspects of soil science, plant science, plant breeding, animal science and use of radiation in food preservation.

E. C. Humphries

\section{SCHOOL NATURAL HISTORY SOCIETIES}

$\mathrm{T}$

HE value of voluntary societies to the corporate life of the school and its fuller development is well brought out in three recent reports. The first, from Blundell's School, gives details of special Sunday evening lectures which are arranged by the Science Society and to which speakers of distinction have been invited over a period of many years. The hundredth of the meetings was celebrated during the year under review when the Society proudly welcomed back Mr. W. H. Dowdeswell, who had had much to do with the Society's foundation.

The role of the society in stimulating the pursuit of knowledge and truth for their own sakes is shown by the original investigations which form the bulk of the report. J. H. Becket describes observations made on catches in moth traps placed at ground-level and at a height of $80 \mathrm{ft}$. An account of experiments to compare soil temperatures under glass and polythene eloches with that of unprotected soil is given by W. L. Slater, while investigations of the flora of the Grand Western Canal are cxamined by C. Little. How woodlice maintain themselves in a moist environment has been investigated by A. J. S. Wearing; A. Lamb gives an account of the effieiency of the pollination mechanism in Arum maculatum. There is also a description of pollen and pollination in rhododendrons by A. Ridge.
Much of the report of the Rugby School Natural History Society is taken up with an account by J. A. D. Hope of his ornithological observations on the Isle of May for a short period in 1956. Hope was primarily concerned with records of the plumage and characteristics, voice and behaviour of the shag, the kittiwake and the fulmar; his essay is not unworthy of much more experienced ornithologists. Besides details of special lectures, the report contains information about the activities of the many sections comprising the Society. These include the museum, vivarium, library, zoological and entomological section ; wffiliated sections, the proceedings of which are described, include architecture, meteorology, photography, astronomy, railways, wireless, aeromodelling and philately. The Society has much to be proud of.

This is also true of the Oundle School Natural History Society, the report of which is mainly eoncerned with records of mammals, birds, fish, butterflies and moths, dragonflies, rotifers, crustaceans and plants observed in the neighbourhood of Oundle. An interesting account of laboratory animals shows that axolotls, African clawed toads, stick insects, salamanders, eyed lizards and geckoes, various British lizards and tropical fish were all under observation some time during 1956.

\section{OXFORD BOTANIC GARDEN}

$T$ HE Botanic Garden at Oxford, which is the oldest in Britain, was founded and endowed as a Physic Garden by the Earl of Danby in 1621 . The Garden was intended for "the improvement of learning" with special regard for the study of 'simples' or drug plants. It was laid out on the site of the old Jews' burying ground opposite Magdalen College, from which the Garden is still leased by the University.

In 1642 the Garden was ready, and Danby, having failed to secure the services of the King's gardener, John Tradescant, appointed Jacob Bobart, an old Brunswick soldier, as 'Keeper'-indeed, as 'Hereditary Keeper'. During the difficult years that followed, Bobart began to collect garden plants, mainly for their interest in medicine, and in 1648 he published a catalogue of 600 native British plants and twice as many from abroad.

A professor of botany was appointed by Charles II in 1669 but the post was not endowed, and the care of the Garden and even the duties of teaching largely lay in the hands of Bobart and later of his son; the younger Bobart made some of the first experiments on sexual reproduction, using male and female plants of the indigenous campion. Many of the plants that he cultivated, especially West Indian ferns, are probably growing in the Garden to-day.

Fifteen years after the death of Bobart a chair of botany was finally endowed by William Sherard. The new professors followed the custom of the century rather than the example of Bobart : teaching ceased. The herbarium grew, but the plants were neglected. In these circumstances, it was by instinct rather than by instruction that Gilbert White, the naturalist, and Sir Joseph Banks, who later founded and stocked the gardens at Kew, visited the Physic Garden as undergraduates and gained a not too favourable impression of botany as a systematic study. 